\section{Notice of elections to Craft Committees of the BDA}

Nominations are sought for election to seats on:

- Armed Forces Committee

- Central Committee for University Educators and Researchers

- Central Committee for Hospital Dental Services

- Dental Public Health Committee

- England Community Dental Services Committee

- General Dental Practice Committee

- Northern Ireland Dental Practice Committee

- Northern Ireland Community Dentists Committee

- Scottish Public Dental Services Committee

- Wales General Dental Practice Committee.

Committees play a vital role in coalescing the opinions of members in each dental craft and reporting this back to the Principal Executive Committee alongside work to develop policy in their respective jurisdiction and negotiations with commissioners, employers and legislators.

Term of office: successful candidates will assume their places in spring 2022 and will serve until the end of the triennium, discharging their responsibilities in early 2025.

More information about this and other BDA elections can be found at the BDA elections website: www.bda.org/ elections.

Nomination forms must be submitted online by 17.00 on Monday 14 March 2022. A link to the online nomination portal can be found at www.bda.org/elections.

For more information about the elections to the Councils or the role of a Council member, please contact the BDA's Election Manager Stephen Skelton on 02075634141 or stephen.skelton@bda.org.

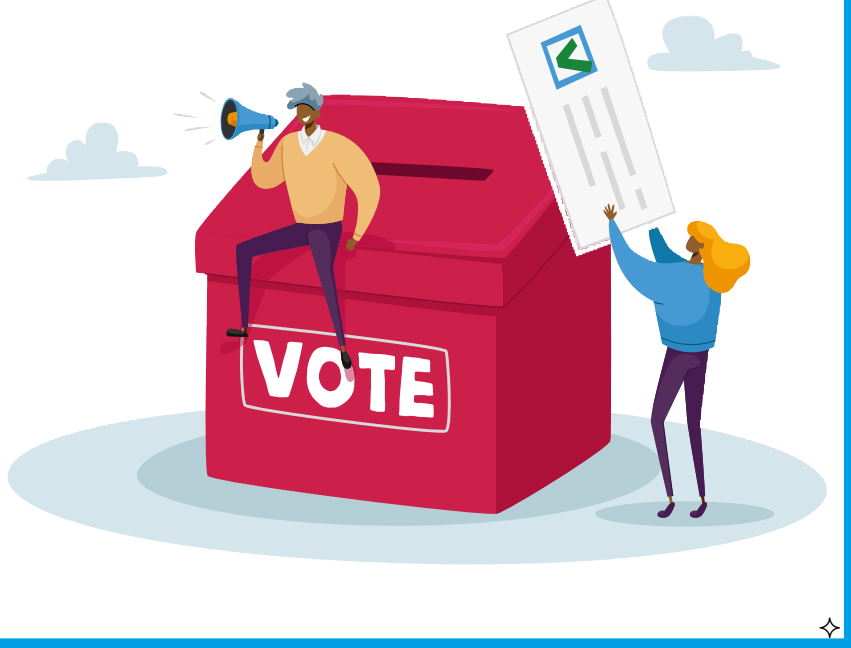

Notice of elections to the Country Councils of the BDA

Nominations are sought for election to seats on:

- English Council

- Northern Ireland Council

- Scottish Council

- Welsh Council.

Councils have the following remit:

- To provide regular advice and comment to the Principal Executive Committee (PEC) as a consultative committee

- To consider and advise the PEC on all matters relating to dentistry within their country

- To advise the PEC on all aspects of policy within their country, facilitating external expert and member input to policy formation where required

- To receive regular reports from the PEC, to enable the Council to debate and comment on the activities of the PEC

- To liaise with branches and sections.

Elected members of country councils will be called upon to form an Interim Principal Executive Committee, if the Principal Executive Committee resigns, is dissolved, or becomes inquorate. This means they temporarily take responsibility as Directors of the Association and direction of the Association as a trade union in these circumstances, until fresh elections are completed.

The Country Councils play a vital role in ensuring that the Principal Executive Committee, which is concerned with the strategic direction and governance of the Association, is kept in touch with the views and concerns of members. Country Council members are the 'voice of members' to the Principal Executive Committee and senior management team.

The Country Councils together constitute the United Kingdom Council which, amongst other functions, considers an annual report from the Principal Executive Committee on its strategic priorities and activities.

Term of office: successful candidates will assume their places in spring 2022 and will serve until the end of the triennium, discharging their responsibilities in early 2025.

More information about this and other BDA elections can be found at the BDA elections website www.bda.org/elections.

Nomination forms must be submitted online by 17.00 on Monday 14 March 2022. A link to the online nomination portal can be found at www.bda.org/elections.

For more information about the elections to the Councils or the role of a Council member please contact the BDA's Election Manager Stephen Skelton on 02075634141 or email stephen.skelton@bda.org. 